\title{
Modeling and forecasting exchange rate volatility: comparison between EEC and Developed countries
}

\author{
Article history: \\ Received: 22 August 2014 \\ Sent for revision: 1 October 2014 \\ Received in revised form: 20 January 2015 \\ Accepted: 3 February 2015 \\ Available online: 1 April 2015
}

\begin{abstract}
The main objective of this study is to test the hypothesis that exchange rates in emerging countries are more sensitive to negative shocks than positive ones, and that developed ones do not exhibit this same pattern, at least not with the same intensity. In order to measure the involved risk, symmetric and asymmetric GARCH models are applied. The accuracy of exchange rate volatility forecast is evaluated using the Mincer-Zarnowitz regression based test and Diebold and Mariano test (DM test). The daily exchange rate returns of HUF/USD, RON/USD and RSD/USD for EEC countries and, the EUR/USD, GBP/USF and JPY/USD for developed countries are analysed for the period January 3, 2000 to April 15, 2013, in respect. Estimation results confirmed superiority of $\mathrm{GARCH}$ model in comparison to asymmetric GARCH models. Results of predictability of conditional variance indicate that GARCH model offers superior performance of forecasting in both of EEC and developed countries. Only in case of Romanian lei TGARCH outperformed GARCH model.
\end{abstract}

Keywords: Exchange Rate Volatility, GARCH models, EEC countries, Developed countries, Mincer-Zarnowitz regression based test, Diebold and Mariano test (DM test)

\section{Modeliranje i predviđanje deviznog kursa: komparacija zemalja Istočne Evrope i razvijenih zemalja}

Apstrakt: Osnovni cilj ovoga rada jeste testiranje hipoteze da su devizni kursevi u zemljama u razvoju osetljiviji na negativne šokove u odnosu na

\footnotetext{
${ }^{1}$ Faculty of Business Economy and Entrepreneurship, sinisamiletic72.bgd@gmail.com 
Miletić S.: Modeling and forecasting exchange rate volatility: comparison between...

pozitivne $i$ da razvijene zemlje ne pokazuju isti obrazac, bar ne sa istim intenzitetom. U cilju merenja tržišnih rizika primenjeni su simetrični GARCH model kao i tri asimetrična GARCH modela. Tačnost prediđanja volatilnosti deviznih kurseva ocenjena je primenom nekoliko najčešće korišćenjih kriterijuma: Mincer-Zarnowitz-ovog regresionog testa i Diebold i Mariano testa (DM test). Dnevni prinosi deviznih kurseva HUF/USD, RON/USD i RSD/USD za zemlje istočne Evrope i, EUR/USD, GBP/USF $i$ JPY/USD za razvijene zemlje analizirani su u periodu od 03. januara 2000 do 15. aprila 2013 godine. Ocenjeni rezultati potvrđuju superiornost GARCH modela u poređenju sa ostalim modelima. Rezultati predviđanja uslovne volatilnosti pokazuju da GARCH modeli poseduju superiornije performance predviđanja kako $u$ zemljama Istočne Evrope tako i u razvijenim zemljama. Samo u slučaju rumunskog leja TGARCH model se pokazao kao superiornijim modelom predviđanja uslovne varijanse u odnosu na simetrični GARCH model.

Ključne reči: volatilnost deviznih kurseva, GARCH modeli, zemlje Istočne Evrope, razvijene zemlje, Mincer-Zarnowitz-ev regresioni test, Diebold $i$ Mariano test (DM test).

\section{Introduction}

Modeling exchange rate volatility has gained a great importance particularly after the collapse of the Bretton Woods agreement when major industrial countries has chosen to shift towards floating exchange rate from fixed exchange rate regime. Since then, there has been an extensive debate about the topic of exchange rate volatility and its potential influence on welfare, inflation, international trade as well as its role in security valuation, profitability and risk management and investment analysis. Consequently, a number of models have been developed in empirical finance literature to investigate this volatility across different regions and countries (Suliman, 2012). The traditional measure of volatility as represented by variance and standard deviation is unconditional and does not recognize interesting patterns in asset volatility, e.g., time-varying and clustering properties (Olowe, 2009). Researchers have introduced various models to explain and predict these patterns in volatility. One such approach is represented by time-varying volatility models, which were expressed by Engle (1982) as autoregressive conditional heteroskedasticity $(\mathrm{ARCH})$ model and extended by Bollerslev (1986) into generalized ARCH (GARCH) model. These models recognize the difference between the conditional and the unconditional volatility of stochastic process, where the former varies over time while the latter remains constant (McMillan and Thupayagale 2010). 
Miletić S.: Modeling and forecasting exchange rate volatility: comparison between...

The vulnerability of emerging economies is clearly evidenced by the behaviour of their exchange rates, which were very volatile. With the exceptions of those countries that adopt fixed exchange rate, emerging countries generally suffer from large capital flight to any domestic bad signal or systematic risk. Meanwhile, developed countries tend to be more stable in relation to their currencies, even if they are not immune to financial crisis (Carvalho Grirbeler 2010).

The main objective of this study is to test the hypothesis that exchange rates in emerging countries are more sensitive to negative shocks than positive ones, and that developed ones do not exhibit this same pattern, at least not with the same intensity. In order to measure the involved risk, symmetric and asymmetric GARCH models are applied. The accuracy of exchange rate volatility forecast is evaluated using the Mincer-Zarnowitz regression based test and Diebold and Mariano test (DM test).

The paper is organized as follows. Literature review is presented in the second chapter. Chapter three describes the data and methodology employed. The fourth chapter presents the results of empirical analysis. Finally, concluding remarks are given in the fifth chapter.

\section{Literature review}

The majority of studies have concentrated on bilateral exchange rates between developed countries (see for example Hsie 1989, Mundaca 1991, Johston and Scott 2000). In addition, in last few years many researchers have concentrated in volatility forecasting in emerging countries (see for example Blaban 2004, Longmore and Robinson 2004, Ng Cheong Vee et.al. 2011).

Despite the fact that there is a large amount of research in volatility forecasting, a limited number of papers gauge the forecast accuracy of exchange rate volatility models in emerging as opposed to developed countries. Sandoval (2006), tested hypothesis that exchange rates in seven countries in Asia and Latin America (Colombia, Brasil, Chile, Mexico, South Korea, Thailand and India) are asymmetric for positive and negative shocks. Author used traditional GARCH, GJR-GARCH and EGARCH models. Using the Akaike and Schwartz criteria, besides the likelihood ratio test, the author found that four of seven currencies are asymmetric. In relation to forecast, the symmetric models outperformed the asymmetric ones. Therefore, the finding of this study was that emerging countries did not show widespread evidence of asymmetry. Carvalho Griebeler (2010) using the family of ARCH models estimated and forecasted the conditional variances of exchange rates in Brasi, Mexico and Singapore, representing emerging countries, and the Euro Zone, UK and Japan, representing the developed one, through 1999 to 2008 
Miletić S.: Modeling and forecasting exchange rate volatility: comparison between...

period. Author results suggested that there is no relationship between the country being either developed or emerging, and its best fit is given by a model symmetrical or asymmetrical. Moreover, the predictability of the conditional variance of symmetric and asymmetric GARCH models was also not connected with the fact that the country belongs to emerging or developed ones. Antonakakis and Darby (2012) investigated the daily exchange rate returns of CLP/USD, CYP/USD, BWP/USD and MUR/USD in case of developing countries and CHF/USD, JPY/USD, GBP/USD and NOK/USD in case of industrialized countries. Authors found that in case of industrialized countries FIGARCH model performed best over all the forecasting horizons tested, while in case of developing countries IGARCH model results in substantial gains in terms of the in-sample results and out-of-sample forecasting performance.

\section{Data and Methodology}

The dataset consists of the daily returns of exchange rates Hungarian forint (HUF), Romanian lei (RON), Serbian dinar (RSD), EU euro (EUR), Great Britain pound (GBP) and Japonica yen (JPY) all against the US dollar obtained from national Central bank websites. The study covers the period January 3, 2000 to April 15, 2013 for HUN/USD, January 3, 2003 to April 15, 2013 for RSD/USD and January 3, 2005 to April 15, 2013 for ROL/USD, in respect. For exchange rate, we compute daily logarithmic returns, $r_{t}=\left(\log P_{t}\right.$ $\left.\log P_{\mathrm{t}-1}\right) * 100$.

\subsection{GARCH type models}

The GARCH $(p, q)$ model was first developed by Bollerslev (1986) as a response to several drawbacks of the ARCH (p) of Engle (1982). When applied to the volatility of financial time series, a GARCH $(p, q)$ process can be written as:

$\sigma_{t}^{2}=\alpha_{0}+\sum_{i=1}^{q} \alpha_{i} \varepsilon_{t-i}^{2}+\sum_{j=1}^{p} \beta_{j} \sigma_{t-j}^{2}$,

Where $\varepsilon_{t}$ is random component with the properties of white noise, size of parameters $\alpha$ and $\beta$ in the equation determines the observed short-term volatility dynamics obtained from series of returns. The high value of coefficient $\beta$ indicates that shocks to conditional variance need a long time to disappear, so the volatility is constant. The high value of the coefficient $\alpha$ means that volatility reacts intensively to changes in the market. In order to have non-explosive process, $\alpha+\beta$ is restricted to be less than one. 
Miletić S.: Modeling and forecasting exchange rate volatility: comparison between...

In order to capture asymmetry Nelson (1991) proposed exponential GARCH process or EGARCH for the conditional variance:

$$
\log \sigma_{t}^{2}=\alpha_{0}+\sum_{i=1}^{q} \beta_{i} g\left(\frac{\varepsilon_{t-i}}{\sigma_{t-i}}\right)+\sum_{j=1}^{p} \alpha_{j} \log \sigma_{t-j}^{2}
$$

Asymmetric relation between returns and volatility change is given as function $g\left(\frac{\varepsilon_{t}}{\sigma_{t}}\right)$, which represent linear combination of $\left|\frac{\varepsilon_{t}}{\sigma_{t}}\right|$ and $\frac{\varepsilon_{t}}{\sigma_{t}}$ :

$$
g\left(\frac{\varepsilon_{t}}{\sigma_{t}}\right)=\theta\left(\left|\frac{\varepsilon_{t}}{\sigma_{t}}\right|-E\left|\frac{\varepsilon_{t}}{\sigma_{t}}\right|\right)+\gamma\left(\frac{\varepsilon_{t}}{\sigma_{t}}\right)
$$

where $\theta$ and $\mathrm{y}$ are parameters that have to be estimated.

First part of equation, $\theta\left(\left|z_{t}\right|-E\left|z_{t}\right|\right)$, captures the size effect, while second part, $\mathrm{\gamma}\left(\mathrm{z}_{\mathrm{t}}\right)$, captures the leverage effect, where $z_{t}=\varepsilon_{t} / \sigma_{t}$.

Zakoian (1994) proposed TGARCH $(p, q)$ model as alternative to EGARCH process, where asymmetry of positive and negative innovations is incorporated in the model by using indicator function:

$$
\sigma_{t}^{2}=\alpha_{0}+\sum_{i=1}^{q}\left(\alpha_{i} \varepsilon_{t-i}^{2}\right)+\sum_{i=1}^{q}\left(\gamma_{i} d\left(\varepsilon_{t-i}<0\right) \varepsilon_{t-i}^{2}\right)+\sum_{j=1}^{p}\left(\beta_{j} \sigma_{t-j}^{2}\right)
$$

where $\gamma_{i}$ are parameters that have to be estimated, $d(\cdot)$ denotes the indicator function defined as:

$$
d\left(\varepsilon_{t-i}<0\right)= \begin{cases}1, & \varepsilon_{t-i}<0 \\ 0 & \varepsilon_{t-i} \geq 0\end{cases}
$$

TGARCH model allows good news, $\left(\varepsilon_{\mathrm{t}-1}>0\right)$, and bad news, $\left(\varepsilon_{\mathrm{t}-1}<0\right)$, to have different effects on the conditional variance. For instance, in the case of TGARCH $(1,1)$ process, good news has an impact of $\alpha_{i}$, while bad news has an impact of $\alpha_{i}+y_{i}$. For $y_{i}>0$, the leverage effect exists.

APARCH $(p, q)$ process, proposed by Ding, Granger and Engle (1993), can be written as: 
Miletić S.: Modeling and forecasting exchange rate volatility: comparison between...

$$
\sigma_{t}^{\delta}=\alpha_{0}+\sum_{i=1}^{q} \alpha_{i}\left(\left|\varepsilon_{t-i}\right|-\gamma_{i} \varepsilon_{t-i}\right)^{\delta}+\sum_{j=1}^{p}\left(\beta_{j} \sigma_{t-j}^{\delta}\right)
$$

Parameter $\delta$ in the equation denotes exponent of conditional standard deviation, while parameter $\gamma$ describes asymmetry effect of good and bad news on conditional volatility. Positive value of $y$ means that negative shocks from previous period have higher impact on current level of volatility, and otherwise.

\subsection{Forecasting evaluation}

In Zarnowitz (1969) regression based test, the realized volatility is regressed on constant and forecast volatility:

$r_{\text {ealized, } t+1}=\alpha+\beta \sigma_{\text {forecast, } t+1}+\varepsilon_{t}$

A separate test is conducted for each model to be unbiased, the parameters $\alpha$ and $\beta$ should be taking the values 0 and 1 respectively. In addition, the $R^{2}$ (goodness-of-fit) of the regression is used as a measurement of predictive power of various models concluded. The model with the largest $\mathrm{R}^{2}$ indicates that the realized volatility can be appropriately explained by the forecast volatility, and therefore has the most powerful forecasting ability.

The Diebold-Mariano test (1995) is a complementary method to compare forecast of two different models in terms of the expected loss observed when using them. This expected loss is calculated following a loss function. Following to the DM test a predefined loss function is specified and express as:

$d_{t}=f\left(e_{t 1}\right)-f\left(e_{t 2}\right)$

Hence, one can test the null hypothesis $d_{t}=0$ of equal forecast accuracy. If the null hypothesis is rejected, then the model with the smallest forecast error is significantly superior to the other model.

\section{Results of empirical analysis}

\subsection{Properties of data}

Plots of the data are presented in Figure 1. As may be seen, in the period of crisis it can be noticed a significant depreciation of the exchange rates in EEC 
Miletić S.: Modeling and forecasting exchange rate volatility: comparison between...

countries, while in case of developed countries it can be noticed a significant appreciation of the exchange rates.

Figure 1. Daily Exchange Rates vs. US Dollar period January 2000 - April 2013
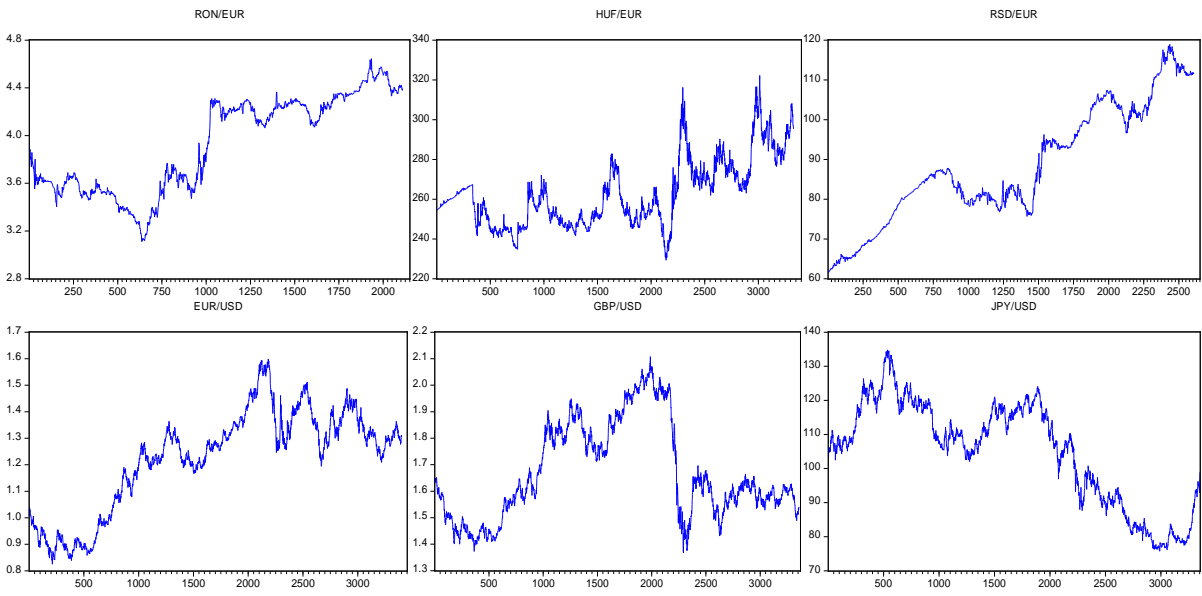

Source: Author's calculations

Table 1 shows the results of unit root test for daily exchange rate returns series. The Augmented Dickey-Fuller test and Phillips-Perron test statistics for all exchange rate returns are highly significant, i.e. the values are less than their critical values at $1 \%, 5 \%$ and $10 \%$ level, thereby suggesting the rejection of null hypothesis of the presence of unit root in the return series.

Table 1. Unit Root Test of the Daily Exchange Rates

\begin{tabular}{|c|c|c|c|c|c|c|c|c|}
\hline & \multicolumn{4}{|c|}{ Augmented Dickey-Fuller test } & \multicolumn{4}{|c|}{ Phillips-Perron test } \\
\hline & \multirow[t]{2}{*}{ Statistic } & \multicolumn{3}{|c|}{ Critical values } & \multirow[t]{2}{*}{ Statistic } & \multicolumn{3}{|c|}{ Critical values } \\
\hline & & $\begin{array}{l}1 \% \\
\text { level }\end{array}$ & $\begin{array}{l}5 \% \\
\text { level }\end{array}$ & $\begin{array}{l}10 \% \\
\text { level }\end{array}$ & & $\begin{array}{l}1 \% \\
\text { level }\end{array}$ & $\begin{array}{l}5 \% \\
\text { level }\end{array}$ & $\begin{array}{l}10 \% \\
\text { level }\end{array}$ \\
\hline RON & $-43.098(0.00)$ & -3.433 & -2.862 & -2.567 & $-43.018(0.00)$ & -3.433 & -2.862 & -2.567 \\
\hline HUF & $-59.159(0.00)$ & -3.432 & -2.862 & -2.567 & $-59.176(0.00)$ & -3.432 & -2.862 & -2.567 \\
\hline RSD & $-46.495(0.00)$ & -3.432 & -2.862 & -2.567 & $-46.535(0.00)$ & -3.432 & -2.862 & -2.567 \\
\hline EUR & $-58.539(0.00)$ & -3.432 & -2.862 & -2.567 & $-58.539(0.00)$ & -3.432 & -2.862 & -2.567 \\
\hline GBP & $-56.102(0.00)$ & -3.433 & -2.862 & -2.567 & $-56.089(0.00)$ & -3.433 & -2.862 & -2.567 \\
\hline JPY & $-59.695(0.00)$ & -3.432 & -2.862 & -2.567 & $-59.793(0.00)$ & -3.432 & -2.862 & -2.567 \\
\hline
\end{tabular}

Note: $P$ values of corresponding test statistics are given in parentheses.

Source: Author's calculations.

Notice in Figure 2 that, unlike the level, the returns are stationary (outcome confirmed by ADF and PP test). Additionally, one can observe that the 
Miletić S.: Modeling and forecasting exchange rate volatility: comparison between...

assumption of constant variance is not valid for all series. Volatility clustering is clearly visible in all cases. The effect of the global financial crisis, although this represents a relatively short period in the entire sample, also appears to have strong influence on the exchange rate variability in observed countries. Note also that the magnitude of effects of global financial crisis is similar in both EEC and developed countries.

Figure 2. Volatility of Daily Exchange Rate Returns period January 2000 April 2013
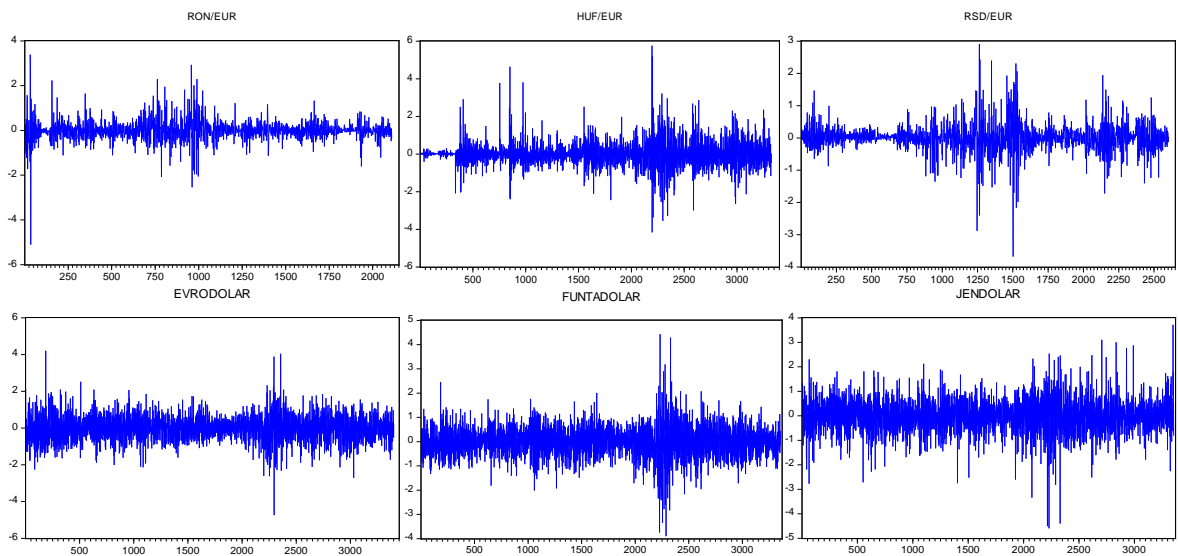

Source: Author's calculations

Figure 3. Quantile-Quantile Plots of Daily Exchange Rate Returns
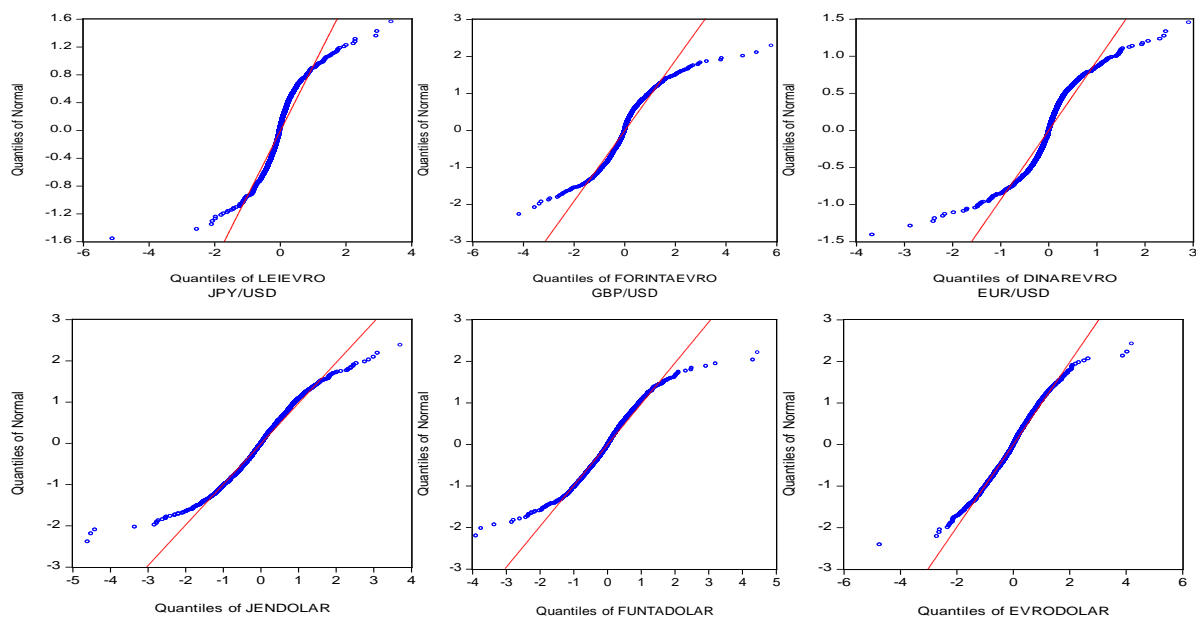

Source: Author's calculations 
Miletić S.: Modeling and forecasting exchange rate volatility: comparison between...

The quantiles of an empirical distribution are plotted against the quantiles of a normal distribution. From the Figure 3 it is clear that QQ plot is not linear and that empirical distribution differs from the hypothesized normal distribution. The plot poses the characteristic S-shape indicating that there is no significant skewness, but the tails are heavier than a normal distribution (Andersen et.al., 2000).

Table 2 indicates that the daily exchange rate returns are not normally distributed. In most cases skewness is evident; kurtosis is in all cases greater than 3 and the Jarque-Bera statistics are highly significant. Positive skewness indicates depreciations of exchange rate in EEC countries as opposed to appreciations in the developed countries. The coefficient of excess kurtosis is in all cases much greater than 3 indicating the distribution of the returns is leptokurtic, which means that the distribution has fatter tails. ARCH-LM test indicates presence of time varying volatility, and Box-Ljung statistics indicate evidence of autocorrelation in both standardized and squared standardized residuals.

Table 2. Descriptive statistics of Daily Exchange Rate Returns

\begin{tabular}{|c|c|c|c|c|c|c|}
\hline & Skewness & Kurtosis & JB & $\mathrm{Q}(10)$ & $\mathrm{Q}^{2}(10)$ & ARCH-LM (10) \\
\hline RON & 0.300 & 6.474 & $\begin{array}{l}1091.89 \\
(0.00)\end{array}$ & $\begin{array}{l}38.69 \\
(0.00)\end{array}$ & $\begin{array}{l}576.12 \\
(0.00)\end{array}$ & $274.63(0.00)$ \\
\hline HUF & 0.297 & 6.379 & $\begin{array}{l}1629.63 \\
(0.00)\end{array}$ & $\begin{array}{l}14.08 \\
(0.01)\end{array}$ & $\begin{array}{l}1321.0 \\
(0.00)\end{array}$ & $494.25(0.00)$ \\
\hline RSD & 0.151 & 5.472 & $\begin{array}{l}673.73 \\
(0.00)\end{array}$ & $\begin{array}{l}41.29 \\
(0.00)\end{array}$ & $\begin{array}{l}745.84 \\
(0.00)\end{array}$ & $332.54(0.00)$ \\
\hline EUR & -0.002 & 5.428 & $\begin{array}{l}835.52 \\
(0.00)\end{array}$ & $\begin{array}{l}22.86 \\
(0.02) \\
\end{array}$ & $\begin{array}{l}449.52 \\
(0.00)\end{array}$ & $258.70(0.00)$ \\
\hline GBP & -0.042 & 7.000 & $\begin{array}{l}2237.70 \\
(0.00)\end{array}$ & $\begin{array}{l}22.29 \\
(0.01)\end{array}$ & $\begin{array}{l}1026.5 \\
(0.00)\end{array}$ & $482.94(0.00)$ \\
\hline JPY & -0.291 & 6.641 & $\begin{array}{l}1900.87 \\
(0.00)\end{array}$ & $\begin{array}{l}30.02 \\
(0.02)\end{array}$ & $\begin{array}{l}138.02 \\
(0.00)\end{array}$ & $107.80(0.00)$ \\
\hline
\end{tabular}

Source: Author's calculations. Note: $P$ values of corresponding test statistics are given in parentheses.

\subsection{Estimation results for EEC countries}

Conducted empirical test indicates that the return distributions are not characterized by normality. Due to skewness and excess kurtosis of daily financial return distributions, estimates based with assumption that residuals follow normal distribution has its drawbacks. Hence, instead of the normal distribution we are going to concentrate on estimation of the various models under the Student's $t$ distribution since they take into account the phenomenon of leptokurtosis and skewness in the probability density function as opposed to the normal distribution. 
Miletić S.: Modeling and forecasting exchange rate volatility: comparison between...

The estimated parameters by GARCH type models for EEC exchange returns are presented in Tables 3, 4 and 5 respectively.

The estimation results of $\operatorname{GARCH}(1,1)$ model show that neither AR nor MA component in the mean equation is significant except in the case of RSD, where AR component is significant, but estimated parameter is very small (0.071). As far as conditional variance equation concern, intercept (c), ARCH $(\alpha)$ and GARCH term $(\beta)$ are statistically significant at the $5 \%$ level and with expected sign for all return series. Results of Ljung-Box Q -test statistics show that autocorrelation for the standardized residuals are statistically insignificant at $5 \%$ level for all lags. This shows that means are well specified in all models. The Ljung-Box $\mathrm{Q}^{2}$-statistics of the squared standardized residuals are insignificant at $5 \%$ level for all lags, except for RSD at lag 30.

The TGARCH $(1,1)$ model also has appropriate statistical characteristics in all three cases. The parameter for asymmetric volatility response $(\mathrm{Y})$ is positive and significant, which indicate presence of asymmetry effects. Autocorrelation and $\mathrm{ARCH}$ effects do not exist in standardized residuals of estimated TGARCH $(1,1)$ models.

The estimation results of EGARCH $(1,1)$ model indicate that estimated parameter $\theta$ is positive and significant for all exchange rate returns. This means that positive shocks (that cause depreciation of national currency) generate more volatility than negative shocks. The estimated parameter $\mathrm{y}$ is positive and insignificant for RON and RSD return series, while in case of HUF is positive and significant. However, in the case of HUF diagnostics for residuals is not entirely satisfactory, since there is evidence of serial correlation in the squared standardized residuals and heteroskedasticity.

The estimation results of APARCH $(1,1)$ model indicate that estimated parameter $\mathrm{y}$ is negative and insignificant for RON and RSD return series, while in case of HUF is negative and significant, indicating that positive shocks (that cause depreciation) from the previous period have higher impact on conditional variance. Thus, APARCH $(1,1)$ model for HUF has appropriate statistical characteristics.

According to modified Akaike criteria too, GARCH model best describes conditional variance of exchange rates in Romania, Serbia and Hungary. 
Miletić S.: Modeling and forecasting exchange rate volatility: comparison between...

Table 3. Parameter estimation of the GARCH models with Student's $t$ distribution of the standardized residuals for RON

\begin{tabular}{|c|c|c|c|c|}
\hline & GARCH & TGARCH & EGARCH & APARCH \\
\hline \multicolumn{5}{|l|}{ Mean equation } \\
\hline Constant & $-0.025(0.08)$ & & & \\
\hline \multicolumn{5}{|l|}{$\mathrm{AR}(1)$} \\
\hline \multicolumn{5}{|l|}{ MA(1) } \\
\hline \multicolumn{5}{|c|}{ Volatility equation } \\
\hline C & $0.009(0.00)$ & $0.013(0.00)$ & $-0.121(0.00)$ & $0.010(0.00)$ \\
\hline$\alpha$ & $0.064(0.00)$ & $0.092(0.00)$ & & $0.062(0.00)$ \\
\hline$\beta$ & $0.922(0.00)$ & $0.907(0.00)$ & $0.983(0.00)$ & $0.925(0.00)$ \\
\hline$\theta$ & & & $0.145(0.00)$ & \\
\hline$y$ & & $0.039(0.04)$ & $0.021(0.07)$ & $-0.127(0.12)$ \\
\hline$\delta$ & & & & $1.847(0.00)$ \\
\hline \multicolumn{5}{|c|}{ Number of degrees of freedom } \\
\hline $\mathrm{v}$ & 9 & 9 & 9 & 9 \\
\hline \multicolumn{5}{|c|}{ Specification test } \\
\hline $\mathrm{Q}(15)$ & $21.92(0.11)$ & $21.46(0.12)$ & $24.06(0.06)$ & $22.28(0.09)$ \\
\hline $\mathrm{Q}(30)$ & $30.92(0.41)$ & $30.48(0.44)$ & $34.40(0.26)$ & $31.55(0.38)$ \\
\hline $\mathrm{Q}^{2}(15)$ & $15.69(0.40)$ & $13.94(0.53)$ & $18.90(0.21)$ & $15.98(0.38)$ \\
\hline $\mathrm{Q}^{2}(30)$ & $29.40(0.49)$ & $25.34(0.70)$ & $33.31(0.30)$ & $28.70(0.53)$ \\
\hline ARCH-LM (15) & $16.40(0.35)$ & $14.43(0.49)$ & $19.45(0.19)$ & $16.46(0.35)$ \\
\hline ARCH-LM (30) & $27.46(0.59)$ & $24.22(0.55)$ & $30.76(0.42)$ & $26.47(0.65)$ \\
\hline $\mathrm{AIC}$ & 1.003799 & 1.004748 & 1.004951 & 1.004899 \\
\hline
\end{tabular}

Source: Author's calculations. Note: $P$ values of corresponding test statistics are given in parentheses

Table 4. Parameter estimation of the GARCH models with Student's $t$ distribution of the standardized residuals for HUF

\begin{tabular}{|c|c|c|c|c|}
\hline & GARCH & TGARCH & EGARCH & APARCH \\
\hline \multicolumn{5}{|l|}{ Mean equation } \\
\hline Constant & $-0.030(0.03)$ & & & \\
\hline \multicolumn{5}{|l|}{$\mathrm{AR}(1)$} \\
\hline \multicolumn{5}{|l|}{$\mathrm{MA}(1)$} \\
\hline \multicolumn{5}{|c|}{ Volatility equation } \\
\hline c & $0.010(0.00)$ & $0.012(0.00)$ & $-0.087(0.00)$ & $0.015(0.00)$ \\
\hline$\alpha$ & $0.051(0.00)$ & $0.071(0.00)$ & & $0.051(0.00)$ \\
\hline$\beta$ & $0.938(0.00)$ & $0.941(0.00)$ & $0.986(0.00)$ & $0.928(0.00)$ \\
\hline$\theta$ & & & $0.111(0.00)$ & \\
\hline $\mathrm{Y}$ & & $0.053(0.00)$ & $0.039(0.00)$ & $-0.282(0.00)$ \\
\hline$\delta$ & & & & $1.961(0.00)$ \\
\hline \multicolumn{5}{|c|}{ Number of degrees of freedom } \\
\hline $\mathrm{V}$ & 10 & 10 & 9 & 10 \\
\hline \multicolumn{5}{|c|}{ Specification test } \\
\hline $\mathrm{Q}(15)$ & $12.79(0.61)$ & $14.32(0.50)$ & $16.08(0.37)$ & $13.96(0.52)$ \\
\hline $\mathrm{Q}(30)$ & $21.54(0.87)$ & $23.19(0.80)$ & $25.25(0.71)$ & $22.90(0.00)$ \\
\hline $\mathrm{Q}^{2}(15)$ & $23.46(0.07)$ & $21.22(0.13)$ & $25.26(0.00)$ & $17.80(0.27)$ \\
\hline $\mathrm{Q}^{2}(30)$ & $42.75(0.06)$ & $41.56(0.07)$ & $48.34(0.01)$ & $36.68(0.18)$ \\
\hline ARCH-LM (15) & $23.38(0.07)$ & $20.73(0.14)$ & $27.34(0.02)$ & $17.55(0.28)$ \\
\hline ARCH-LM (30) & $41.50(0.07)$ & $39.75(0.17)$ & $45.59(0.03)$ & $35.58(0.22)$ \\
\hline $\mathrm{AIC}$ & 1.00241 & 1.003012 & 1.003423 & 1.003614 \\
\hline
\end{tabular}

Source: Author's calculations.

Industrija, Vol.43, No.1, 2015 
Miletić S.: Modeling and forecasting exchange rate volatility: comparison between...

Table 5. Parameter estimation of the GARCH models with Student's $t$ distribution of the standardized residuals for RSD

\begin{tabular}{|c|c|c|c|c|}
\hline & GARCH & TGARCH & EGARCH & APARCH \\
\hline \multicolumn{5}{|l|}{ Mean equation } \\
\hline \multicolumn{5}{|l|}{ Constant } \\
\hline $\mathrm{AR}(1)$ & $0.071(0.00)$ & $0.070(0.00)$ & $0.072(0.00)$ & $0.070(0.00)$ \\
\hline \multicolumn{5}{|l|}{$\mathrm{MA}(1)$} \\
\hline \multicolumn{5}{|c|}{ Volatility equation } \\
\hline C & $0.009(0.00)$ & $0.009(0.00)$ & $-0.092(0.00)$ & $0.009(0.00)$ \\
\hline$\alpha$ & $0.050(0.00)$ & $0.063(0.00)$ & & $0.040(0.00)$ \\
\hline$\beta$ & $0.933(0.00)$ & $0.932(0.00)$ & $0.986(0.00)$ & $0.929(0.00)$ \\
\hline$\theta$ & & & $0.107(0.00)$ & \\
\hline $\mathrm{Y}$ & & $0.023(0.05)$ & $0.016(0.08)$ & $-0.110(0.11)$ \\
\hline$\delta$ & & & & $2.446(0.00)$ \\
\hline \multicolumn{5}{|c|}{$\begin{array}{l}\text { Number of degrees of } \\
\text { freedom }\end{array}$} \\
\hline $\mathrm{v}$ & 12 & 12 & 12 & 12 \\
\hline \multicolumn{5}{|l|}{ Specification test } \\
\hline$Q(15)$ & $13.97(0.49)$ & $14.04(0.44)$ & $14.23(0.45)$ & $13.89(0.45)$ \\
\hline $\mathrm{Q}(30)$ & $33.78(0.24)$ & $34.27(0.25)$ & $35.08(0.20)$ & $34.02(0.23)$ \\
\hline$Q^{2}(15)$ & $15.35(0.35)$ & $15.20(0.36)$ & $17.96(0.20)$ & $14.55(0.040)$ \\
\hline $\mathrm{Q}^{2}(30)$ & $45.93(0.02)$ & $45.71(0.02)$ & $50.63(0.00)$ & $45.22(0.02)$ \\
\hline ARCH-LM (15) & $14.98(0.45)$ & $14.89(0.45)$ & $17.28(0.30)$ & $14.30(0.50)$ \\
\hline ARCH-LM (30) & $43.50(0.05)$ & $43.53(0.05)$ & $46.77(0.02)$ & $43.34(0.05)$ \\
\hline $\mathrm{AIC}$ & 1.003843 & 1.004612 & 1.004710 & 1.004732 \\
\hline
\end{tabular}

Source: Author's calculations.

\subsection{Estimation results for developed countries}

The estimated parameters by GARCH type models for the exchange rate returns for developed countries are presented in Tables 6,7 and 8 respectively.

The estimation results of $\operatorname{GARCH}(1,1)$ model show that neither AR nor MA component in the mean equation is significant, except in the case of JPY, where AR component is significant and negative, but estimated parameter is very small (-0.043). In the conditional variance equation, intercept (c), $\mathrm{ARCH}$

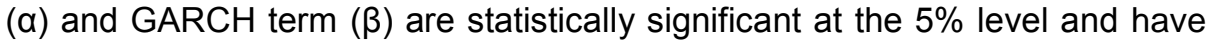
expected sign. In the case of EUR, the GARCH-M term is significant showing the exchange rate risk is compensated in the exchange rate market. The conditional standard deviation $\sigma$ is significant, suggesting that if there is an effect of risk on the mean return. Model has satisfactory explanatory power.

Results of estimating different types of asymmetric ARMA $(m, s)-G A R C H(p, q)$ model with assumption that the residuals follow Student's $t$ distribution for developed countries suggest the following conclusion. 
Miletić S.: Modeling and forecasting exchange rate volatility: comparison between...

Table 6. Parameter estimation of the GARCH models with Student's $t$ distribution of the standardized residuals for EUR

\begin{tabular}{|c|c|c|c|c|c|}
\hline & GARCH & GARCH-M & TGARCH & EGARCH & APARCH \\
\hline \multicolumn{6}{|l|}{ Mean equation } \\
\hline Constant & $0.019(0.05)$ & $0.060(0.00)$ & $0.019(0.05)$ & & $0.018(0.05)$ \\
\hline \multicolumn{6}{|l|}{$\overline{A R}(1)$} \\
\hline \multicolumn{6}{|l|}{$\mathrm{MA}(1)$} \\
\hline$\sigma$ & & $-0.112(0.04)$ & & & \\
\hline \multicolumn{6}{|c|}{ Volatility equation } \\
\hline $\mathrm{C}$ & $0.002(0.01)$ & $0.002(0.01)$ & $0.002(0.01)$ & $-0.06(0.00)$ & $0.003(0.03)$ \\
\hline$\alpha$ & $0.032(0.00)$ & $0.032(0.00)$ & $0.032(0.00)$ & & $0.038(0.00)$ \\
\hline$\beta$ & $0.963(0.00)$ & $0.961(0.00)$ & $0.963(0.00)$ & $0.993(0.00)$ & $0.962(0.00)$ \\
\hline$\theta$ & & & & $0.077(0.00)$ & \\
\hline$y$ & & & $0.002(0.07)$ & $0.002(0.07)$ & $0.002(0.07)$ \\
\hline$\delta$ & & & & & $1.406(0.00)$ \\
\hline \multicolumn{6}{|c|}{$\begin{array}{l}\text { Number of degrees } \\
\text { of freedom }\end{array}$} \\
\hline $\mathrm{v}$ & 13 & 12 & 13 & 13 & 13 \\
\hline \multicolumn{6}{|l|}{ Specification test } \\
\hline $\mathrm{Q}(15)$ & $16.93(0.32)$ & $16.54(0.34)$ & $17.00(0.31)$ & $18.15(0.25)$ & $17.39(0.29)$ \\
\hline$Q(30)$ & $26.15(0.66)$ & $25.58(0.69)$ & $26.23(0.66)$ & $27.31(0.60)$ & $26.48(0.65)$ \\
\hline Q2(15) & $6.55(0.96)$ & $7.13(0.95)$ & $6.63(0.96)$ & $7.55(0.94)$ & $6.99(0.95)$ \\
\hline Q2(30) & $23.35(0.80)$ & $23.67(0.78)$ & $23.40(0.79)$ & $23.58(0.79)$ & $23.56(0.79)$ \\
\hline ARCH-LM (15) & $6.57(0.96)$ & $7.16(0.95)$ & $6.65(0.96)$ & $7.60(0.93)$ & $7.03(0.95)$ \\
\hline ARCH-LM (30) & $23.57(0.79)$ & $23.84(0.77)$ & $23.63(0.78)$ & $24.08(0.76)$ & $23.88(0.77)$ \\
\hline AIC & 1.002355 & 1.002944 & 1.003003 & 1.003945 & 1.003001 \\
\hline
\end{tabular}

Source: Author's calculations

Table 7. Parameter estimation of the GARCH models with Student's $t$ distribution of the standardized residuals for GBP

\begin{tabular}{|c|c|c|c|c|}
\hline & GARCH & TGARCH & EGARCH & APARCH \\
\hline \multicolumn{5}{|l|}{ Mean equation } \\
\hline Constant & $0.009(0.27)$ & & & \\
\hline \multicolumn{5}{|l|}{$\operatorname{AR}(1)$} \\
\hline \multicolumn{5}{|l|}{$\mathrm{MA}(1)$} \\
\hline \multicolumn{5}{|c|}{ Volatility equation } \\
\hline $\mathrm{C}$ & $0.002(0.00)$ & $0.002(0.00)$ & $-0.077(0.00)$ & $0.002(0.03)$ \\
\hline$\alpha$ & $0.038(0.00)$ & $0.022(0.00)$ & & $0.032(0.01)$ \\
\hline $\bar{\beta}$ & $0.954(0.00)$ & $0.955(0.00)$ & $0.991(0.00)$ & $0.955(0.00)$ \\
\hline$\theta$ & & & $0.077(0.00)$ & \\
\hline Y & & $0.028(0.00)$ & $-0.017(0.01)$ & $0.194(0.01)$ \\
\hline$\delta$ & & & & $2.226(0.00)$ \\
\hline \multicolumn{5}{|c|}{$\begin{array}{l}\text { Number of degrees of } \\
\text { freedom }\end{array}$} \\
\hline $\mathrm{v}$ & 12 & 13 & 12 & 13 \\
\hline \multicolumn{5}{|c|}{ Specification test } \\
\hline$Q(15)$ & $11.85(0.69)$ & $12.54(0.63)$ & $13.62(0.55)$ & $12.42(0.64)$ \\
\hline $\mathrm{Q}(30)$ & $28.40(0.54)$ & $29.01(0.51)$ & $31.47(0.39)$ & $28.79(0.52)$ \\
\hline Q2(15) & $9.24(0.86)$ & $10.61(0.77)$ & $10.98(0.75)$ & $10.77(0.77)$ \\
\hline $\mathrm{Q} 2(30)$ & $26.10(0.65)$ & $30.89(0.42)$ & $32.95(0.32)$ & $30.79(0.42)$ \\
\hline ARCH-LM (15) & $8.90(0.88)$ & $10.98(0.75)$ & $10.70(0.77)$ & $10.35(0.79)$ \\
\hline ARCH-LM (30) & $26.29(0.66)$ & $32.95(0.32)$ & $33.01(0.32)$ & $31.37(0.39)$ \\
\hline $\mathrm{AIC}$ & 1.00238 & 1.00298 & 1.00298 & 1.00358 \\
\hline
\end{tabular}

Source: Author's calculations

Industrija, Vol.43, No.1, 2015 
Miletić S.: Modeling and forecasting exchange rate volatility: comparison between...

Based on Ljung-Box Q-test statistics on both raw (Q) and squared $\left(Q^{2}\right)$ standardized residuals and Engle's LM ARCH test for the presence of ARCH effects in the series, in the case of GBP all asymmetric GARCH $(1,1)$ models have appropriate statistical characteristics, while in the case of JPY EGARCH $(1,1)$ model has appropriate statistical characteristics.

According to modified Akaike criteria, GARCH model best describes conditional variance of exchange rates in EU, Great Britain and Japan.

Table 8. Parameter estimation of the GARCH models with Student's $t$ distribution of the standardized residuals for JPY

\begin{tabular}{|c|c|c|c|c|}
\hline & GARCH & TGARCH & EGARCH & APARCH \\
\hline \multicolumn{5}{|l|}{ Mean equation } \\
\hline \multicolumn{5}{|l|}{ Constant } \\
\hline $\mathrm{AR}(1)$ & $-0.043(0.01)$ & $-0.042(0.01)$ & $-0.039(0.01)$ & $-0.039(0.01)$ \\
\hline \multicolumn{5}{|l|}{$\mathrm{MA}(1)$} \\
\hline \multicolumn{5}{|c|}{ Volatility equation } \\
\hline $\mathrm{C}$ & $0.005(0.00)$ & $0.006(0.00)$ & $-0.079(0.00)$ & $0.009(0.00)$ \\
\hline$\alpha$ & $0.031(0.00)$ & $0.021(0.00)$ & & $0.043(0.00)$ \\
\hline$\beta$ & $0.956(0.00)$ & $0.955(0.00)$ & $0.984(0.00)$ & $0.951(0.00)$ \\
\hline$\theta$ & & & $0.087(0.00)$ & \\
\hline 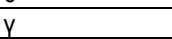 & & $0.018(0.06)$ & $-0.017(0.04)$ & $0.200(0.06)$ \\
\hline$\delta$ & & & & $1.144(0.00)$ \\
\hline \multicolumn{5}{|c|}{$\begin{array}{l}\text { Number of degrees of } \\
\text { freedom }\end{array}$} \\
\hline $\mathrm{v}$ & 6 & 6 & 6 & 6 \\
\hline \multicolumn{5}{|c|}{ Specification test } \\
\hline$Q(15)$ & $15.63(0.33)$ & $16.36(0.29)$ & $16.01(0.37)$ & $16.05(0.31)$ \\
\hline $\mathrm{Q}(30)$ & $27.64(0.53)$ & $17.94(0.52)$ & $25.43(0.65)$ & $27.54(0.54)$ \\
\hline Q2(15) & $13.60(0.48)$ & $13.22(0.50)$ & $15.07(0.37)$ & $14.92(0.38)$ \\
\hline Q2(30) & $21.81(0.82)$ & $23.09(0.77)$ & $25.43(0.65)$ & $25.04(0.67)$ \\
\hline ARCH-LM (15) & $14.03(0.52)$ & $13.74(0.54)$ & $15.52(0.41)$ & $15.42(0.42)$ \\
\hline ARCH-LM (30) & $23.75(0.78)$ & $25.39(0.70)$ & $28.07(0.56)$ & $27.67(0.58)$ \\
\hline $\mathrm{AIC}$ & 1.002984 & 1.003601 & 1.003581 & 1.003632 \\
\hline
\end{tabular}

Source: Author's calculations

\subsection{Forecast evaluation for EEC countries}

Results of Mincer-Zarnowitz regression test of exchange rate returns for selected EEC presented in table 9 indicate that for all the regression against the sample forecast of the GARCH variance, showed a clear lack of explanatory power and sub-optimality in the model. The null hypothesis (c $=0$ and $\beta=1$ ) was always rejected. The coefficient $R^{2}$ is very low and ranges between 0.121 to 0.145 which indicate low explanatory power of TGARCH and APARCH models. 
Miletić S.: Modeling and forecasting exchange rate volatility: comparison between...

Table 9. Mincer-Zarnowitz regression for EEC countries

\begin{tabular}{|c|c|c|c|c|c|}
\hline \multicolumn{6}{|c|}{ RON } \\
\hline Variable & Coefficient & Std. Error & t-Statistic & Prob. & $c=0 ; \beta=1$ \\
\hline C & 0.033884 & 0.052362 & 0.647104 & 0.5176 & YES \\
\hline HTGARCH & 0.940699 & 0.054997 & 17.10469 & 0.0000 & $\mathrm{NO}$ \\
\hline \multirow{2}{*}{\multicolumn{6}{|c|}{$\frac{\mathrm{R} 2=0.121977}{\mathrm{HUF}}$}} \\
\hline & & & & & \\
\hline Variable & Coefficient & Std. Error & t-Statistic & Prob. & $c=0 ; \beta=1$ \\
\hline C & -0.005853 & 0.058360 & -0.100286 & 0.9201 & YES \\
\hline HTGARCH & 1.013297 & 0.043040 & 23.54318 & 0.0000 & $\mathrm{NO}$ \\
\hline \multicolumn{6}{|c|}{$\mathrm{R} 2=0.143067$} \\
\hline Variable & Coefficient & Std. Error & t-Statistic & Prob. & $c=0 ; \beta=1$ \\
\hline $\mathrm{C}$ & -0.000139 & 0.057863 & -0.002398 & 0.9981 & YES \\
\hline HAPARCH & 1.004781 & 0.042227 & 23.79486 & 0.0000 & $\mathrm{NO}$ \\
\hline \multicolumn{6}{|c|}{$R 2=0.145694$} \\
\hline \multicolumn{6}{|c|}{ RSD } \\
\hline Variable & Coefficient & Std. Error & t-Statistic & Prob. & $c=0 ; \beta=1$ \\
\hline C & -0.041244 & 0.039950 & -1.032390 & 0.3020 & YES \\
\hline HTGARCH & 1.086913 & 0.057077 & 19.04284 & 0.0000 & $\mathrm{NO}$ \\
\hline \multicolumn{6}{|c|}{$\mathrm{R} 2=0.122319$} \\
\hline
\end{tabular}

Source: Author's calculations

Table 10 show the application of Diebold-Mariano test. The main objective of the test is to distinguish between two forecasts in terms of the minimization of certain loss function. Results of Diebold-Mariano test confirmed the results obtained before. Note that symmetric model outperforming TGRACH forecast in the case of Hungarian forint and Serbian dinar. Only in the case of Romania lei, TGARCH outperforming the GARCH forecast.

Table 10. Diebold-Mariano test EEC countries

\begin{tabular}{|c|c|c|c|c|}
\hline \multicolumn{5}{|c|}{ RON } \\
\hline \multicolumn{5}{|c|}{ Dependent variable: d(garch-tgarch) } \\
\hline Variable & Coefficient & Std. Error & t-Statistic & Prob. \\
\hline C & 0.161245 & 0.050938 & 3.165536 & 0.0016 \\
\hline \multicolumn{5}{|c|}{ HUF } \\
\hline \multicolumn{5}{|c|}{ Dependent variable: d(garch-tgarch) } \\
\hline Variable & Coefficient & Std. Error & t-Statistic & Prob. \\
\hline C & 0.000740 & 0.001065 & 0.694443 & 0.4875 \\
\hline \multicolumn{7}{|c|}{ Dependent variable: d(garch-aparch) } \\
\hline Variable & Coefficient & Std. Error & t-Statistic & Prob. \\
\hline C & 0.000413 & 0.000319 & 1.296437 & 0.1949 \\
\hline \multicolumn{7}{|c|}{ RSD } \\
\hline Variable & Coefficient & Std. Error & t-Statistic & Prob. \\
\hline C & $-1.91 E-05$ & $2.39 E-05$ & -0.799252 & 0.4242 \\
\hline
\end{tabular}

Source: Author's calculations 
Miletić S.: Modeling and forecasting exchange rate volatility: comparison between...

\subsection{Forecast evaluation for developed countries}

Results of Mincer-Zarnowitz regression test (table 11) and Diebold-Mariano test (table 12) of exchange rate returns for developed countries show similar pattern as in CEE countries, i.e. that GARCH model offers superior performance of forecasting conditional variance.

Table 11. Mincer-Zarnowitz regression for developed countries

\begin{tabular}{|c|c|c|c|c|c|}
\hline \multicolumn{6}{|c|}{ EUR } \\
\hline Variable & Coefficient & Std. Error & t-Statistic & Prob. & $c=0 ; \beta=1$ \\
\hline $\mathrm{C}$ & 0.042324 & 0.030623 & 1.382111 & 0.1670 & YES \\
\hline HGARCHM & 0.891920 & 0.058625 & 15.21393 & 0.0000 & NO \\
\hline \multicolumn{6}{|c|}{ R2 $=0.063791$} \\
\hline \multicolumn{6}{|c|}{ GBP } \\
\hline Variable & Coefficient & Std. Error & t-Statistic & Prob. & $c=0 ; \beta=1$ \\
\hline $\mathrm{C}$ & -0.006927 & 0.021864 & -0.316818 & 0.7514 & YES \\
\hline HTGARCH & 1.027169 & 0.044755 & 22.95075 & 0.0000 & $\mathrm{NO}$ \\
\hline \multicolumn{6}{|c|}{$\mathrm{R} 2=0.135801$} \\
\hline Variable & Coefficient & Std. Error & t-Statistic & Prob. & $c=0 ; \beta=1$ \\
\hline $\mathrm{C}$ & -0.060898 & 0.023920 & -2.545846 & 0.0109 & NO \\
\hline HEGARCH & 1.192506 & 0.052754 & 22.60515 & 0.0000 & NO \\
\hline \multicolumn{6}{|c|}{$\mathrm{R} 2=0.132279$} \\
\hline Variable & Coefficient & Std. Error & t-Statistic & Prob. & $c=0 ; \beta=1$ \\
\hline $\mathrm{C}$ & -0.000882 & 0.021644 & -0.040757 & 0.9675 & YES \\
\hline HAPARCH & 1.007321 & 0.043812 & 22.99185 & 0.0000 & $\mathrm{NO}$ \\
\hline \multicolumn{6}{|c|}{$\mathrm{R} 2=0.136222$} \\
\hline \multicolumn{6}{|c|}{ JPY } \\
\hline Variable & Coefficient & Std. Error & t-Statistic & Prob. & $c=0 ; \beta=1$ \\
\hline $\mathrm{C}$ & -0.049014 & 0.045499 & -1.077257 & 0.2814 & YES \\
\hline HEGARCH & 1.120397 & 0.097480 & 11.49356 & 0.0000 & NO \\
\hline \multicolumn{5}{|c|}{$\mathrm{R} 2=0.037927$} & \\
\hline
\end{tabular}

Source: Author's calculations

Table 12. Diebold-Mariano test for developed countries

\begin{tabular}{|c|c|c|c|c|}
\hline \multicolumn{5}{|c|}{ EUR } \\
\hline \multicolumn{5}{|c|}{ Dependent variable: d(garch-garch-m) } \\
\hline Variable & Coefficient & Std. Error & t-Statistic & Prob. \\
\hline $\mathrm{C}$ & 0.000863 & 0.001132 & 0.762455 & 0.4458 \\
\hline \multicolumn{5}{|c|}{ GBP } \\
\hline \multicolumn{5}{|c|}{ Dependent variable: d(garch-tgarch) } \\
\hline Variable & Coefficient & Std. Error & t-Statistic & Prob. \\
\hline $\mathrm{C}$ & 0.000128 & 0.000202 & 0.635093 & 0.5254 \\
\hline \multicolumn{5}{|c|}{ Dependent variable: d(garch-egarch) } \\
\hline Variable & Coefficient & Std. Error & t-Statistic & Prob. \\
\hline $\mathrm{C}$ & 0.000128 & 0.000202 & 0.635093 & 0.5254 \\
\hline \multicolumn{5}{|c|}{ Dependent variable: $d$ (garch-aparch) } \\
\hline Variable & Coefficient & Std. Error & t-Statistic & Prob. \\
\hline $\mathrm{C}$ & 0.000128 & 0.000202 & 0.635093 & 0.5254 \\
\hline \multicolumn{5}{|c|}{ JPY } \\
\hline \multicolumn{5}{|c|}{ Dependent variable: d(garch-egarch) } \\
\hline Variable & Coefficient & Std. Error & t-Statistic & Prob. \\
\hline $\mathrm{C}$ & $3.64 \mathrm{E}-05$ & 7.14E-05 & 0.508893 & 0.6109 \\
\hline
\end{tabular}

Source: Author's calculations 
Miletić S.: Modeling and forecasting exchange rate volatility: comparison between...

\section{Concluding remarks}

The main objective of these study is to test the hypothesis that exchange rates in emerging countries are more sensitive to negative shocks than positive ones, and that developed ones do not exhibit this same pattern, at least not with the same intensity. In order to measure the involved risk, symmetric and asymmetric GARCH models are applied. The accuracy of exchange rate volatility forecast is evaluated using the Mincer-Zarnowitz regression based test and Diebold and Mariano test (DM test). The daily exchange rate returns of HUF/USD, RON/USD and RSD/USD for EEC countries and, the EUR/USD, GBP/USF and JPY/USD for developed countries are analysed for the period January 3, 2000 to April 15, 2013, in respect.

Estimation results indicate that there is no difference between EEC and developed countries. Results of predictability of conditional variance indicate that GARCH model offers superior performance of forecasting conditional variance in both of EEC and developed countries. Only in case of Romanian lei, TGARCH outperformed GARCH model.

Finally, the initial hypothesis of the study was not verified. Moreover, the difficulty of exchange rate returns predictability was also present, because both symmetric and asymmetric GARCH models do not demonstrate superiority in forecasting future values of exchange rate volatility during the sample period.

The difficulty of forecasting is related to the peculiarities of the period, which includes in its observation period of Financial crisis and European sovereign debt crisis. Therefore, in future study author will consider this problem using dummy variable.

\section{References}

Andersen, T.G., Bollerslev, T., Diebold, F.X., \& Labys, P. (2000). Exchange Rate Returns Standardized by Realized Volatility Are (Nearly) Gaussian. Multinational Finance Journal, 4, 159-179.

Antonakakis, N., \& Darby, J. (2012). Forecasting Volatility in Developing Countries' Nominal Exchange Returns. MPRA Paper No.40875.

Bollerslev, T. (1986). Generalized autoregressive conditional heteroskedasticity. Journal of Econometrics, 31(3), 307-327. doi:10.1016/03044076(86)90063-1

Griebeler, C.M. (2010). Models for Forecasting Exchange Rate Volatility: A Comparison between Developed and Emerging Countries. IMPA. 
Miletić S.: Modeling and forecasting exchange rate volatility: comparison between...

Diebold, F.X., \& Mariano, R.S. (1995). Comparing Predictive Accuracy. Journal of Business \& Economic Statistics, 13(3), 253-263. doi:10.1080/07350015.1995.10524599

Ding, Z., Granger, C.W.J., \& Engle, R.F. (1993). A long memory property of stock market returns and a new model. Journal of Empirical Finance, 1(1), 83-106. doi:10.1016/0927-5398(93)90006-d

Engle, R.F. (1982). Autoregressive Conditional Heteroscedasticity with Estimates of the Variance of United Kingdom Inflation. Econometrica, 50(4), 987-1007. doi:10.2307/1912773

Hsie, D.A. (1989). Modeling Heteroskedasticity in Daily Foreign-Exchange Rates. Jornal of Business \& Economic Statistic,7(3),

Longmore, R., \& Robinson, W. (2004). Modeling and Forecasting Exchange Rate Dymanics: An Application of Asymmetric Volatility Models. Bank of Jamaica, Researche Services Department. Working Paper WP 2004/3.

McMillan, D., \& Thupayagale, P. (2010). Evaluating Stock Index Return Value-at-Risk Estimates in South Africa: Comparative Evidence for Symmetric, Asymmetric and Long Memory GARCH Models. Journal of Emerging Market Finance, 9(3), 325-345. doi:10.1177/097265271000900304

Mincer, J., \& Zarnowitz, V. (1969). The Evaluation of Economic Forecast. In J. Mincer (Ed.), Economic Forecast and Expectations. New York: NBER.

Mundaca, G.G. (1991). The Volatility of the Norwegian Currency Basket. Scandinavian Journal of Economics, 93(1), 53-73. doi:10.2307/3440421

Nelson, D.B. (1991). Conditional Heteroskedasticity in Asset Returns: A New Approach. Econometrica, 59(2), 347-70. doi:10.2307/2938260

Cheong, V.N.D., Gonpot, N.P., \& Sookia, N. (2011). Forecasting Volatility of USD/MUR Exchange Rate using a GARCH $(1,1)$ model with GED and Student's$\mathrm{t}$ errors. University of Mauritius Research Journal, 17(1), 1-14. doi:10.4314/umrj.v17i1.70728

Olowe, R.A. (2009). Modelling Naira/Dollar Exchange Rate Volatility: Application of GARCH And Asymmetric Models.International Review of Business Research Papers, 5(3), 377-398.

Sandoval, J. (2006). Do Asymmetric Garch models fit better rate volatilities on emerging markets. In Working Paper Universidad Externado do Colombia, Odeon. (pp. 99-116).

Abdalla, S.Z.S. (2012). Modelling Exchange Rate Volatility using GARCH Models: Empirical Evidence from Arab Countries. International Journal of Economics and Finance, 4(3), 216-229. doi:10.5539/ijef.v4n3p216

Zakoian, J. (1994). Threshold heteroskedastic models. Journal of Economic Dynamics and Control, 18(5), 931-955. doi:10.1016/0165-1889(94)90039-6 